\title{
CONQUER THE ARTWORK: A BOARD GAME FOR TEACHING HISTORY OF ART
}

\author{
MÍRIA SANTANNA DOS SANTOS ${ }^{1}$ * \\ ORCID: https://orcid.org/0000-0002-5429-0993 \\ MARCELO AUGUSTO RAUH SCHMITT ${ }^{2} * *$ \\ ORCID: https://orcid.org/0000-0003-1290-5029 \\ ANDRÉ PERES $2 * * *$ \\ ORCID: https://orcid.org/0000-0003-2510-2305 \\ ELISEO BERNI REATEGUI ${ }^{1} * * * *$ \\ ORCID: https://orcid.org/0000-0002-5025-9710
}

\begin{abstract}
Games may contribute with the learning processes in different knowledge areas. This article describes the development and use of a board game that addresses history of art content, in a quasi-experimental studywith students of the 1st year of secondary education in two public schools. The students' performance was evaluated before and after the intervention, as well as their motivation after using the game. Observational data were collected, as well as photographs, audio recordings and interviews with the participating teachers. In the writing tests, the students who used the game had a performance equivalent to those of the control group, showing a satisfactory motivation level and adequate level of acceptance of the game. The article discusses these results, bringing to the debate not only the use of games in educational contexts, but also the way in which these games are introduced in the classroom. Although the board game developed in this research focuses on specific contents about art in the city of Porto Alegre, Brazil, the game model may be customized by teachers and students and be adapted to address other contents.
\end{abstract}

Keywords: Educational game, motivation, art-education, experimental research

\section{CONQUISTE A OBRA: UM JOGO DE TABULEIRO PARA O ENSINO DE HISTÓRIA DA ARTE}

\footnotetext{
${ }^{1}$ Universidade Federal do Rio Grande do Sul,. Porto Alegre, RS, Brazil.

${ }^{2}$ Instituto Federal de Educação, Ciência e Tenologia do Rio Grande do Sul, IFRS. Porto Alegre, RS, Brazil

* Federal University of Rio Grande do Sul, Brazil/Post-Graduation Program in Informatic in Education. Porto Alegre, RS, Brazil.<miria.santanna@ufrgs.br>

** Full Professor at the Federal Institut of Education, Science and Technology of Rio Grande do Sul, IFRS. Porto Alegre, RS, Brazil.<marcelo.schmitt@poa.ifrs.edu.br>

*** Full Professor at the Federal Institut of Education, Science and Technology of Rio Grande do Sul, IFRS. Porto Alegre, RS, Brazil. <andre.peres@poa.ifrs.edu.br>

**** Full Professor at the Federal University of Rio Grande do Sul, Brazil/Post-Graduation Program in Informatic in Education. Brazil.<eliseoreategui@gmail.com> 
RESUMO: Os jogos podem contribuir com o processo de aprendizagem em diferentes áreas do conhecimento. Este artigo descreve o desenvolvimento e utilização de um jogo de tabuleiro que aborda conteúdos sobre História da Arte, em um estudo quasi-experimental com alunos do primeiro ano do Ensino Médio de duas escolas da rede pública de ensino. O desempenho dos estudantes foi avaliado antes e após a intervenção, bem como sua motivação após a utilização do jogo. Foram coletados dados por meio de observação, gravação de áudio, registro de imagens e realização de entrevista com os professores participantes. Nos testes escritos os alunos que utilizaram o jogo tiveram desempenho equivalente ao do grupo controle, evidenciando níveis satisfatórios de motivação e bom nível de aceitação do jogo. O artigo discute tais resultados, trazendo para o debate não apenas o emprego dos jogos em contextos educacionais, mas também a maneira como são introduzidos em sala de aula. Embora o jogo de tabuleiro desenvolvido nesta pesquisa foque em conteúdos específicos sobre arte da cidade de Porto Alegre, o modelo de jogo pode ser personalizado por professores e estudantes e podem ser feitas versões adaptadas para outros conteúdos.

Keywords: jogo educativo, motivação, arte-educação, pesquisa experimental

\section{CONQUISTA LA OBRA: UN JUEGO DE MESA PARA ENSEÑAR HISTORIA DEL ARTE}

RESÚMEN: Los juegos pueden contribuir al proceso de aprendizaje en distintas áreas del conocimiento. Este artículo describe el desarrollo y uso de un juego de mesa que aborda el contenido de la Historia del Arte en un estudio cuasiexperimental con estudiantes de primer año de secundaria de dos escuelas públicas. Se evaluó el rendimiento de los estudiantes antes y después de la intervención, así como su motivación después de usar el juego. Los datos fueron recolectados mediante observación, grabación de audio, grabación de imágenes y entrevistas con los maestros participantes. En las pruebas escritas, los estudiantes que usaron el juego tuvieron un rendimiento equivalente al del grupo de control, mostrando niveles satisfactorios de motivación y un buen nivel de aceptación del juego. El artículo analiza estos resultados, trayendo al debate no solo el uso de juegos en contextos educativos, sino también la forma en que se introducen en las clases. Aunque el juego de mesa desarrollado en esta investigación se centra en contenidos específicos sobre el arte en la ciudad de Porto Alegre, el modelo de juego puede ser personalizado por profesores y estudiantes y versiones adaptadas para otros contenidos se pueden hacer.

Palabras clave: juego educativo, motivación, educación artística, investigación experimental 


\section{INTRODUCTION}

Literature related to educational games often reports encouraging results regarding the use of these artifacts to support learning processes. One of the main aspects that support the use of games in education is the motivational factor, capable of directing human behavior toward a certain objective (TOHIDI; JABBARI, 2012). However, some studies have also revealed limitations in the use of games in educational contexts, bringing results sometimes not so conclusive (LINDEROTH, 2012).

A literature review in the area also indicated that positive results in the use of educational games are influenced by different student features and the context in which they are (VANDERCRUYSSE; VANDERWAETERE; CLAREBOUT, 2012). In this work we investigated how a board game to support learning of Art History could motivate students and provide results comparable to known practices in art teaching, such as oral lessons associated with atelier activities. The study involved the development of a board game, with game pieces produced with a laser cutter representing works of art of local artists.

In this context, it is important to situate the research, as well as the changes that have occurred in the country in relation to art teaching in the last decades. A particular Brazillian Law that was passed in 1971 (No 5,692), under the denomination of Artistic Education, established that art teaching should be part of the curriculum of elementary school. At that time, short degree courses were implemented, in which a teacher, in only two years, was trained to teach visual arts, music, theater and dance.

The courses were, in general, implemented with a spontaneous vision about art teaching, a laissez-faire approach that allowed students to do "anything" (FRANGE, 2012). This understanding of art as Free Expression is historically and ideologically linked to Modernism, emphasizing personal vision and emotion as a content of expression, with the search for originality as an ideal. Such a conception, according to the critics, caused a discrepancy between the art produced in this period and the art taught in schools (RIZZI, 2012). The contemporary view of art teaching values construction as an artistic procedure, emphasizing cognition in relation to emotion. It also encompasses to "art making" the understanding and access to the cultural heritage of humanity.

In the 90's, the 'Triangular Proposal of Art Teaching' was systematized in Brazil, defending the construction of knowledge in art in three levels: artistic making, reading of images and their contextualization. The proposal involved, in addition to the practices of atelier, the teaching of Art History and appreciation of art images (RIZZI, 2012). However, it is possible to observe that many art teachers did not have adequate training to implement the proposal. According to the 2017 School Census (INEP, 2018), only 41.1\% of the art disciplines in high school in Brazil were taught by teachers with adequate training. In the art subjects of the final years of elementary school, only $31.5 \%$ of the teachers had adequate training. In addition, schools had a low number of hours dedicated to art classes (45 or 50 minutes per week), and teachers had insufficient training, which contributed to the devaluation of visual arts teaching in schools (LOPONTE, 2014).

In such context, it becomes important to develop educational material that may help teachers improve their art teaching in elementary school. This argument is further reinforced when we consider the new generations who expect a more active and motivating school, capable of placing the student at the center of the learning process. These arguments are aligned with the proposal of using games as a play artifact capable of involving students in learning activities. However, in the context of arts education, may play effectively facilitate learning processes and provide adequate levels of motivation? These are the questions that the study presented here tries to answer. In this sense, the development of educational material to explore game play in art teaching may also bring a more interactive proposal to the classroom.

\section{TEACHING AND LEARNING IN THE DOMAIN OF THE ARTS}

The current teaching model still places students as passive subjects in the educational process, in which they are supposed to attend lectures about contents that are often far from their reality and understanding. The global society in which we live, which gives knowledge and information a fundamental role, requires citizens to learn, to develop skills to work in groups, to collaborate and 
share knowledge and experiences. It also requires one to have initiative, to know how to solve problems by making quick decisions and filter information, to be creative, to innovative and able to deal with technologies. However such skills are generally not taught in school, an institution that continues to plan activities in a way that often does not stimulate creativity (MATTAR, 2010).

Art acquires a new importance in this context. Qualified art education with appropriate educational material may foster the development of important cognitive aspects for learning at all levels and fields of knowledge. Visual information has become the most consumed type of information in our society (ACASO, 2006). This is why people need to learn to consciously analyze the images they see on a daily basis. In this sense, one of the important roles of art in schools should be to help students become visually literate (BARBOSA, 2012).

Ana Mae Barbosa, pioneer educator in Art-Education in Brazil, developed in 1987 the Triangular Approach that united historical contextualization, artistic appreciation and artistic making, thus breaking the spontaneous vision of art teaching in schools in the country at the time. However even today, the practices of atelier (painting, drawing, modeling, etc...) are predominant in the art disciplines, proposing practices that are out of context and often unrelated to the universe of art. These practices only deal with the artistic language without getting the students to develop a personal way to express themselves. Besides, these activities are not related with the history of art (MARTINS, 2012). These out of context and spontaneous practices end up by contributing to the devaluation of art teaching in schools (SANTOS, 2008). The continuing use of such practices, besides disqualifying art education, also discourages students, which is problematic considering that motivation is a fundamental learning aspect.

In this context, it is important to introduce teaching practices that capture students' attention and give meaning to contents. In this work a game model has been proposed as an alternative practice for art teaching and learning, trying to understand the contributions and limitations of games in the context of education.

\section{GAMES IN EDUCATION AND THE MOTIVATION CONSTRUCT}

There are several definitions about the concept of gaming. Johann Huizinga, a Dutch anthropologist, published in 1938 a study about games as an element of culture, a pioneering study that examined many of the fundamental features of games and demonstrated their importance in the development of civilization (CALLOIS, 1991). Huizinga considers play as an element that comes before culture, arguing that even animals engage in games in which all the essential elements of human games are already present:

In culture we find play as a given magnitude existing before culture itself existed, accompanying it and pervading it from the earliest beginnings right up to the phase of civilization we are now living in (HUIZINGA, 1949, p. 4).

Salen and Zimmerman (2012) consider games to be a system in which players engage in an artificial conflict, defined by rules and with a result that must be quantifiable. However, from the point of view of education, the definition of play becomes more complex. Gilles Brougère, a French philosopher and specialist in toys and games, argues that play is a social construction. He traced a historical panorama of the use of games in school in his work "Game and Education" (BROUGÈRE, 2003). The history of games in this context reveals the place they have occupied in school, often being used more in the field of recreation than teaching itself. In the last decade, it was possible to observe a strong trend in the use of digital games developed for specific educational purposes, including the projection of scenarios in which games could operate as transforming element in Basic Education (PAULA; VALENTE, 2016). Based on studies in the field of child psychology, the relation between games and child development began to be justified with scientific arguments, serving as the basis to establish a stronger relation between play and education (BROUGÈRE, 1998). With the emergence and diffusion of digital games, the gaming industry gave more visibility to games, creating a field designed only for game design and giving a boost to authorship games (BROUGÈRE, 2015). At this point, games started to be looked from a different perspective, leading to a reinvention of board games, which became more complex and challenging. The production and research of educational games also 
gained new impetus, seeking to produce educational games more attractive, with proposals that brought teachers closer to more active pedagogies.

In the context of games, Piaget (1994) argues that rules games constitute the child's first contact with socialized activities. For the author, children's play has the role of assimilation, because it represents to the child the incorporation of the outside world into their own schemes and desires. Through play the child develops the ability to manipulate and represent signs, which is indispensable for the development of intelligence. The operative value of rules games is also of structural importance. To win it is necessary to coordinate different points of view, to be able to anticipate what players will do, to have, finally, an operative reasoning. It is in this context that the notion of cooperation deepens, which is a "starting point for a series of important processes for the constitution and development of logic" (PIAGET, 1966, p.194). For the author to cooperate is to coordinate operations. Such coordination presupposes the observation of different points of view, considering the perspective of the other and decentralizing the process of reasoning. Such decentration often results in the process of unbalance, a fundamental stage in the learning process.

The understanding of games as a social construction, defended by Brougère (2015), offers a historical trajectory of games that complement the research presented here. In this work, games are seen as the center of the educational process, and not a recreational activity to complement other teaching practices. Therefore, the game is thought as a pedagogical material to work on specific contents, which deepens and broadens the discussion of the role of games in the teaching and learning process. For students who have grown up in the computer and internet age, new learning practices are fundamental, especially for this generation that has developed important skills through games (MATTAR, 2010).

As for the relations between art and games, both are image producers, they bring cultural issues to their context and privilege affection, they unite play to art teaching as a way to facilitate learning processes (SANTOS, 2008, p. 27):

The development of ludic aspects facilitates learning, intrapersonal and interpersonal development collaborates with mental health, preparing [students] for a fertile inner state, facilitating the process of socialization, communication, expression and knowledge construction.

In our contemporary society, the digital gaming industry is one of the most substantial in recent decades. Most of young people play or have already played some kind of video game. However, the school does not yet incorporate these elements that are part of our culture (MATTAR, 2010). Although research about the use of games in education is numerous, the use of games in formal learning contexts could be more effective. The belief that games are just for children and adolescents is an argument that prevents their use in a broader way (GALISI, 2009).

One of the arguments that often supports the use of games in educational activities is related to motivation. This may be understood as one of the main forces that directs and reinforces human behavior (TOHIDI; JABBARI, 2012). Research in the area of motivation assumes that it is present in the execution of any activity, that is, actions are performed only when they are 'energized' by motivation. For this reason, educational material has to exploit aspects related to student motivation.

Different instruments have been developed to assess the level of motivation of an individual while performing an activity. One of these instruments is the Intrinsic Motivation Inventory. It is a multi-dimensional instrument that has the goal of evaluating the subjective experience of participants of lab experiments in relation to a given activity (RYAN, DECI, 2000). Although it has been employed in many studies, including in the area of education, the instrument has a more restrictive context regarding the type of situation in which it may be employed, ideally allowing a more precise control of variables.

As for the model proposed by Keller (1987), it was developed with the specific purpose of finding more effective ways of understanding the main influences of motivation to learn and solve problems. In education, particularly, the author points out that people realize that they do not have an adequate understanding of the motivation construct, especially when they need to design or teach a course on their own. In this context, the author proposes the ARCS model, based on four axes: Attention, Relevance, Confidence and Satisfaction. Attention means that it is necessary to capture 
students' interest by stimulating their curiosity to learn. Relevance refers to the fact that contents should be relevant to the student, meeting their needs. It should also give students a positive attitude towards learning. Confidence may be encouraged by helping students to believe that they may succeed in the proposed activities and may control this process. Satisfaction is achieved by reinforcing the completion of activities.

Savi (2011) developed a model based on the work of Keller (1987), aiming to complement and provide a simple application tool to evaluate the students' motivation to perform an activity without causing major problems in the classroom. The instrument questions the students about their perception about the activities, using a 5-point Likert scale. In this project we opted to use Savi's (2011) instrument to evaluate students' motivation to use the game developed for the teaching and learning of arts, specifically because of the instrument's purpose to be used in educational contexts.

\section{METHODOLOGICAL PROCEDURES}

The study performed in this research had as a main goal to understand how a board game specially developed to work with Art History could contribute with high school students' learning processes. It was also part of the study to evaluate the benefits and limitations of this strategy by comparing it with oral lessons complemented by atelier practices. To answer these questions, a quasiexperimental study was developed with 53 high school students, divided into experimental group and control group. The research was structured in 2 stages, each of them described below.

\section{Building the Game Based on Iterative Design}

The game developed in this research focused on public art works linked to three movements or artistic trends: classicism, modernism and contemporary art. As such works are freely accessible and are in places of the city where students often circulate, they become more accessible than works of art that are in private collections, galleries or museums. On the other hand, they are also better known because they are part of the history and identity of the city, adding meaning to the contents to be presented.

For the development of the game, we chose the Iterative Design methodology, which is used by most board game designers and may be defined as a design process based on "play" (SALEN, ZIMMERMAN, 2012). This approach emphasizes gameplay testing and prototyping. Starting in the first stages of development, a prototype without the qualities of the final product is created, only to define basic rules and the main mechanisms of the game. This prototype is then played and evaluated, and redesign decisions and design improvements are based on the players' experience and use of the prototype. It is then adjusted and used again by the players, in a cyclical process that alternates between prototypes, tests, evaluation and refinement.

Educational games often emphasize cooperation rather than conflict and competition, in an attempt to be politically correct, which also makes them not as stimulating as commercial games. In order to avoid this problem, it is important that the design of an educational game focuses on the player's experience and not necessarily the contents (MATTAR, 2010).

A prototype was initially developed with the definition of basic game mechanics based on three types of information about the works of art: author, date of production, and movement or artistic style. The board consists of the representation of a clipping of the city map, with the location of the works of art and their indications. Letters were also made to include the title and image of the works, as well as other important information for the players.

After delimiting the contents and choosing the information that should compose the game, the main objective of the player was defined, or, more precisely, the conditions of victory and defeat in the game. Then, rules were designed to enable the player to conquer the works of the city, thus providing information on the works he or she would need to conquer. Such information appears on the cards that are distributed to the players. The works are represented by pieces on the board, and docked to the places that correspond to their location.

Following these definitions, a prototype was developed to begin the gameplay tests, which were performed by a group of five collaborators. Following the iterative design methodology, at each test, the players acted as game design critics, suggesting improvements, analyzing mechanics, rules and 
the graphical interface (SALEN, ZIMMERMAN, 2012). All in all, seven gameplay tests were made with this initial group and two more tests were performed with a group of art teachers. After each test, improvements were made to the prototype, improving the graphical interface and striking a balance between randomness and competition, in order to maintain a level of tension that would keep players in the game flow.

A framework was developed for the game considering its art contents (COSTA, 2010), in an attempt to integrate the contents with the game mechanics. The information about the works of art was put into the game in different ways, using images and texts, both on the cards and on the board. This is one of the strategies recommended in the design of educational digital games (MATTAR, 2010). All images, texts and symbols that illustrate the game have some function to the player, looking for a useful design (PRENSKY, 2012) and avoiding the inclusion of information that is not necessary. Figure 1 illustrates the board and parts constructed.

Figure 1 - Final Prototype of the game board "Conquer the Work"

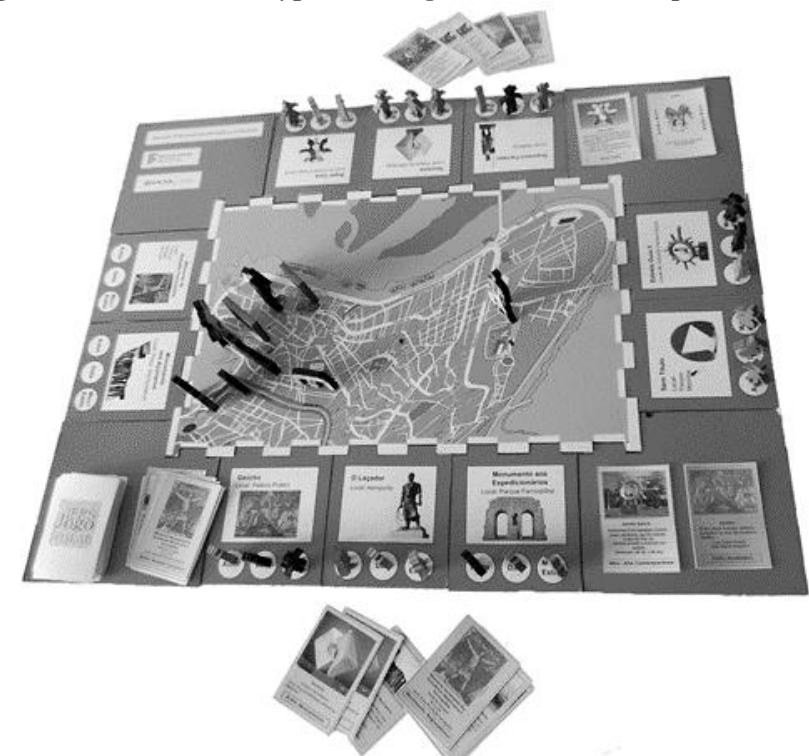

Source: The author (2016)

In order to make it possible for the teachers to customize the game, the tabs of the board, with information about the works of art and where the players mark their moves, became detachable and easily replaceable, allowing new works to be inserted to work on others contents. The pieces of the game representing the works were made in MDF wood, with engravings and cuttings done with a laser cutter in a FabLab (Laboratory of Digital Fabrication). A validation test of the game was also made with high school students in a public school, which made it possible to make adjustments according to the criticisms and suggestions of the target audience of the research. Based on this, a final prototype was developed.

\section{Study for Data Collection and Analysis}

With the prototype completed, the study was performed with the target audience, aiming mainly to evaluate the students' performance in the proposed activities. The research was conducted with the control group and with the experimental group. The control group was composed of 26 students from the 1st year of high school, distributed in two classes: 18 students from school A and 8 students from school B, both in the city of Porto Alegre, Brazil. In these same schools, the tests were performed with the experimental group, which was composed of 27 students from the 1 st year of high school, also distributed in two groups: 19 students from school A and 8 students from school B, as shown in table 1. All participants signed a consent form informing them about the research objectives and explaining the voluntary nature of the activities. 
Table 1 - Organization of the Control Group and Experimental Group

\begin{tabular}{ccc}
\hline & Control Group & Experimental Group \\
\hline School A & 18 & 19 \\
School B & 8 & 8 \\
\hline Total & 26 & 27 \\
\hline \multicolumn{3}{c}{ Source: The author (2018) }
\end{tabular}

The control group participated in two classes taught in two consecutive periods of 45 minutes, totaling one and a half hours. The initial 15 minutes of the class were dedicated to the application of the pre-test, and the final 15 minutes were used for the post-test. The class included an oral presentation of the public works of the city followed by a studio practice in which the students performed re-readings of the works in two or three dimensions.

The experimental group also participated in two classes dedicated to the proposed theme, totaling one hour and a half. However, this group did not have an oral lesson and also did not participate in a workshop practice. After the pre-test ( 15 minutes initial), the students got to know the board game and played in small groups of 4 students for 1 hour. The teacher who presented the game only circulated among the groups to solve doubts and mediate the activity. The final 15 minutes of the class were also used for the post-test with the students.

The pre-test and post-test used with both groups had exactly the same format. The test asked students to write words or information that they knew about the works of art of the city. The goal of the test was to evaluate the students' performance before and after the intervention, observing differences between the use of the game and the oral class followed by the practice of atelier. It is known, of course, that skills developed in studio practices, for example, could not be practiced in the game. Therefore, the research focused specifically on the identification of possible differences between the information that students could remember about the works of art when using the game or working with the oral lesson approach and atelier practice. In addition to pre-test and post-test, the experimental group also answered the questionnaire developed by Rafael Savi (2011), with the goal of assessing their level of motivation during the use of the game.

To complement the research data, images, audio and observation records were made in all meetings with the students of the experimental group and the control group. Unstructured interviews were also conducted with the art teachers who participated in the research, following the development of activities with their students.

\section{RESULTS AND DISCUSSION}

The analysis of the data, regarding the performance of the students in the pre-test showed that both groups had little knowledge about the works of art listed in this study. It was possible to verify that the students initially had some information about the most popular works, such as the statue of the Laçador, considered the symbol of the city, or the work Supercuias, located in the region of the Usina do Gasômetro in Porto Alegre, a cultural space quite frequented and well-known of the city's inhabitants. However, even though they knew the most popular works by their name, they did not know who their authors were or what artistic styles or movements the works of art were affiliated with. In relation to other less popular works of art, little information or comments were brought by the students. Table 2 shows the results achieved by the control group and the experimental group in relation to the pre-test, post-test and the difference between them, considering the students in schools $\mathrm{A}$ and $\mathrm{B}$. The goal of calculating this difference was to look for evidence of how the activities performed allowed the students to refer to previously unknown information about the works of art.

Table 2 - Test results with Control Group and Experimental Group

\begin{tabular}{l|ccc|ccc}
\hline & \multicolumn{3}{|c|}{ Control Group } & \multicolumn{3}{c}{ Experimental Group } \\
& Pre-test & Post-test & Difference & Pre-test & Post-test & Difference \\
School A & 6.05 & 10.5 & 4.45 & 3.6 & 9.5 & 5.9 \\
School B & 3.9 & 8.2 & 4.34 & 2.9 & 7.9 & 5 \\
\hline Average Schools & 4.98 & 9.35 & 4.40 & 3.25 & 8.7 & $\mathbf{5 . 4 5}$ \\
\hline \multicolumn{3}{c}{ Source: The author (2018) } \\
\end{tabular}


Student's t-Test was then used to evaluate the statistical difference between the averages obtained by the students of the experimental group and the control group. The average of the difference between pre-test and post-test was considered in this calculation for classes A and B, values in bold in the table. Results of the t-test showed that the average obtained by the students in the experimental group (average $=5.45$ ), although apparently higher, was statistically equivalent to the average obtained by the students in the control group (average $=4.40$ ) for a $\mathrm{p}$-value $=0.124$. Therefore, regarding the students' performance, it may be stated that the proposed activity with the board game allowed students to achieve a performance equivalent to that achieved by students who participated in the oral lesson complemented by a workshop practice. Such a result is positive from the perspective of the schools' need to diversify their practices and materials to support teaching and learning processes. It is therefore a finding that places games in the same level as other classroom activities, when considering students' performance as a central element of analysis.

In this sense, it should be emphasized that the development of an educational game should not aim, as the main proposal, to "compete" with other strategies such as the practice of atelier, or even lectures. These approaches are important and will certainly continue to be part of teaching and learning practices in schools. However, the existence of a board game to be used in a formal educational context widens the range of possibilities regarding the strategies and tools available to teachers. In this sense, it is important emphasize that the literature in the field of games indicates other benefits derived from the use of these artifacts, such as the development of cognitive abilities, the development of learning by discovery and socialization (SAVI; ULBRICHT, 2008). On this basis, it is possible to affirm that the developed game gives students the possibility to work with art curriculum contents while exploring aspects of interaction, communication and play, elements that are not always present in the classroom.

This study also evaluated the level of motivation of the students who used the game, based on the instrument developed by Savi (2011). The results of this evaluation are presented in Figure 2.

Figure 2 - Percentages of responses regarding student motivation

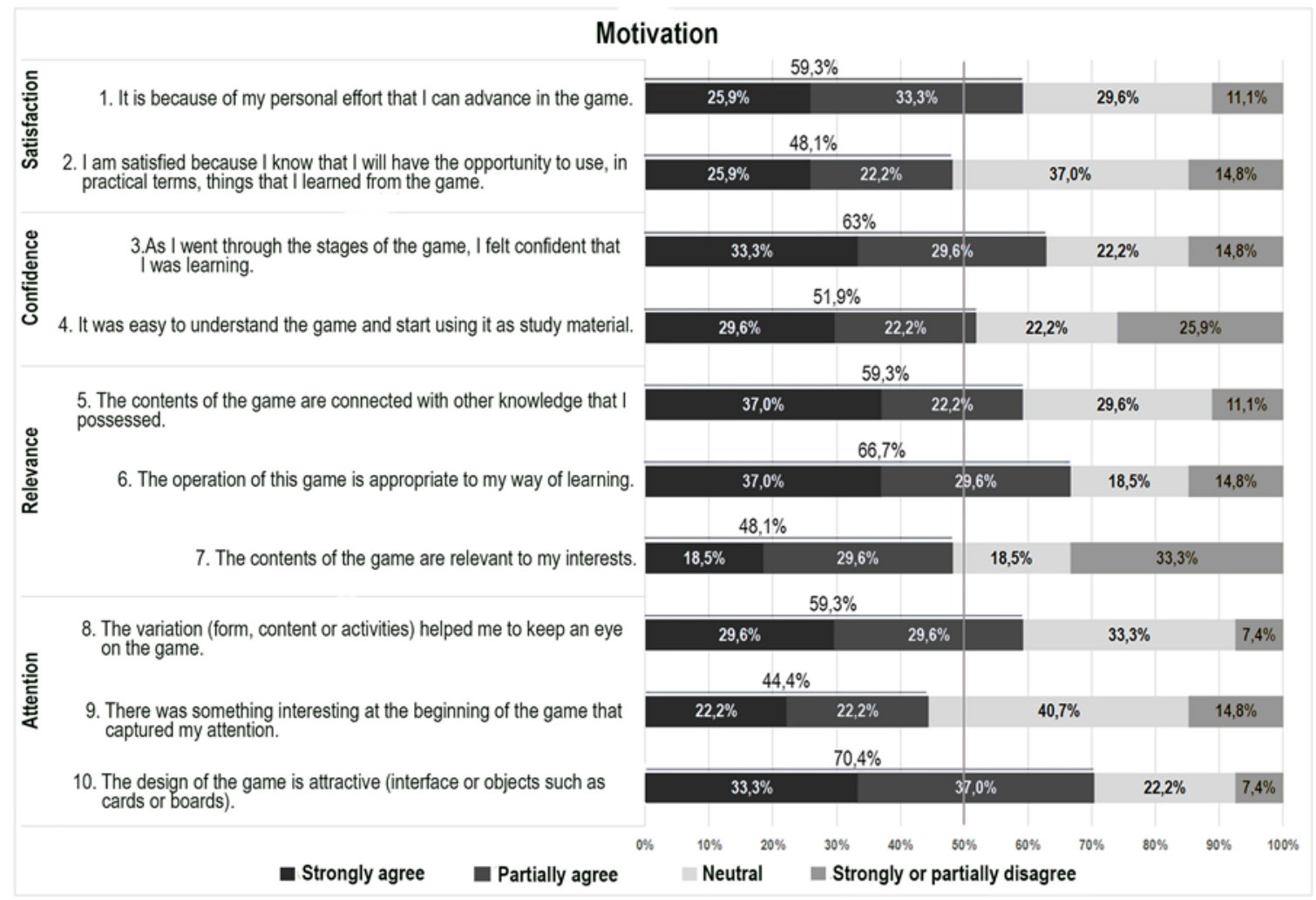

Source: The author (2016) 
Regarding the satisfaction dimension, the average of the answers related to the two questions that made up the question was $53.5 \%$, indicating that this was the percentage of students who strongly or partially agreed with the statements presented. Although this value is positive, the large number of respondents who were neutral or who did not agree with the affirmations were also expressive. The devaluation of arts education may be related to this result, especially when one of the questions asked (2) students precisely about the opportunities they will have to use in practice what they learned from the game. Over the years art has assumed the connotation of ornament, hobby, or simply free expression. This phenomenon has placed art teaching in a secondary sphere in relation to other areas of education (SANTOS, 2008). The hierarchy of school knowledge itself denotes this explicitly or implicitly, insofar as it keeps art teaching at a lower echelon in the school structure (TOURINHO, 2012).

As for the trust dimension, the two items that made up this factor had a satisfactory evaluation, resulting in an average of $57.45 \%$ when the answers were strongly agree and partially agree. It is observed in the frequency chart that most of the students gave positive answers in the items about the ease in understanding the game and the feeling of confidence that they were learning when passing through the stages of the game. The fact that $63 \%$ of the students stated that they felt they were learning when passing through the stages of the game indicates that its structure did not present greater restrictions for the development of the activities. Costa (2010) emphasizes this aspect by stating that a game with pedagogical purposes must have a structure appropriate to the contents, and learning this structure should enable the player to reach his or her goal in the game.

Regarding the relevance dimension, the average values resulted in $58.03 \%$, again considering together the answers agree and strongly agree. Despite the positive value, it is worth mentioning again the students' answers to the explicit question about the relevance of the game in relation to their interests (3rd item of the questionnaire). Only $48 \%$ of the students agreed or strongly agreed with the statement that the contents of the game ware relevant to them. One may again see the reflection of the lack of emphasis that the arts discipline receives in regular education, and the extent to which students have difficulty integrating the contents of the discipline into their set of knowledge and interests. In this context, Silva and Moreira (2016) highlight the damage caused to the teaching of art in Brazil with the proposal of its extinction in 1986, with subsequent ideological and political discussions that led to different reformulations in school curricula. The result is that today there are schools in which there is virtually no discipline today called Visual Arts. And when it exists, it often occupies a minimum space of the curricular matrix with the simple aim of meeting certain legal requirements. In this way, students are unable to make associations that seem relevant to their knowledge about the contents studied in arts. Keller (1987) discusses this aspect, emphasizing the importance that the students be able to establish such associations so that they may give meaning to contents seen in class.

Regarding the attention dimension, the average of the students' answers in the three questions resulted in a value of $58.03 \%$ for the set of answers agree and strongly agree. This is considered a good result especially if we focus on the negative responses to the question, average $9.87 \%$ if we consider the answers disagree and strongly disagree. Attention and motivation are components that are closely linked and, according to Keller (1987), the first requirement to stimulate learning motivation is to obtain and maintain the attention of students by directing it to the appropriate stimuli. Getting the attention is not the hardest, the challenge is to sustain it throughout the process. In this sense, if there was any limiting factor related to this question it could be related to the structure of the game. It is known that deficiencies regarding the aesthetic aspects as well as the mechanics of a game are determinant for its success. However, some issues relating specifically to game building point to positive student feedback, as in the case of question 10. Preliminary tests with game prototypes have also brought positive feedback from players about their aesthetics and gameplay.

Combining the averages obtained in each of the four dimensions (satisfaction, confidence, relevance and attention), we obtain the value $57.01 \%$. This was the percentage of students who agreed or strongly agreed with the statements that showed a good level of motivation. This is a satisfactory value, especially considering the average percentage of students who indicated that they disagreed or strongly disagreed with the statements, reaching $15.54 \%$. A significant number of students were neutral regarding the statements, reaching the average percentage of $27.38 \%$. 
Although the motivation indicators reached satisfactory levels, some information shows why such results were not more positive. Firstly, it was possible to see how some students had difficulty in learning the rules of the game, specially in what the operation of some cards was concerned. Some students reported the difficulty of dealing with the joker cards, which was rebuffed by one of the students saying that these cards made them think, and it was necessary to establish relations to use them. This attitude of paying attention to the information in the charts required more concentration, which some saw as positive, but others saw more resistance. In this sense, Csikszentmihalyi and Nakamura (2014) point out that the level of motivation and concentration of an individual in an activity is related to the degree of the challenge posed by it. When the challenge seems too hard, levels of motivation and concentration may drop, which may have occurred in some situations when using the game. In this sense, it is important to notice that, in the research presented in this article, the game was associated with a certain practice for its presentation and conduction of the activities. Possible changes in these dynamics may improve the perception of some students regarding the level of difficulty imposed by the game.

It was also possible to observe in the answers of the students related to the motivation questionnaire that they often compared the game used in class with other games they used to play. In this sense, it is natural that the game developed as part of this research was at a disadvantage, considering the great teams and resources infinitely larger used in the production of commercial games. It is also worth noting that a large part of the current literature on games in education concerns the use of digital games, exploring their playful potential and their language supposedly close to that known and appreciated by digital natives (PRENSKY, 2001). Is there, therefore, any restriction on the potential of games that do not use this language and rely on older models centered on the interaction between players around a board? Mandryk, Maranan and Inkpen (2002) discuss some of the differences between digital games and board games. While digital games may benefit from simulation environments, unbiased judgment and immersive perception, board games often offer richer interaction among participants, even allowing their rules to be modified, if so agreed upon by the players. The authors emphasize, for example, that the board is, for the most part, present to facilitate interaction between the players, not the game. The results of the research presented here do not make it possible to deepen the discussion about the differences between digital games and board games. However, they bring pertinent questions to guide future research in order to better explore the existing differences between the two types of artifacts with respect to their motivational potential in educational contexts.

An important aspect to highlight is that the teachers who participated in the research evaluated the game in a positive way in an unstructured interview conducted at the end of the project. Three prototypes of the game were donated to one of the schools to meet the demand of one of the teachers who conducted the study in her classes. The teacher made an important move with the intention of incorporating the intervention with the game in the pedagogical proposals of art teaching at her school.

With regard to the observation data, the class records and the analysis of the audios recorded with the experimental group showed that most of the students were very concentrated, totally immersed in the activities proposed with the game. The students' speeches mainly showed their attempt to understand and operate according to the rules of the game, also observing the moves of the opponents, demonstrating attitude of decentration. Often the mediators were called to give explanations about the operation of the game so that everyone could conform to the rules. In this context, the important role of coordination among participants based on established rules is perceived. As Macedo (1997) points out, in order to know the operative value of the rules in a game one must go beyond one's simple knowledge and be able to outline strategies to win. It was also noted that sometimes the rules of the game were adapted by consensus, which is also an evidence of the development of the group's ability to operate together or cooperate.

The teacher at school A reported in the interview that she had never worked with games in the classroom and she liked the experience very much, considering it was very productive. When asked about the students' reaction to the use of the game, she replied: 'I thought it was fantastic ... they were able to concentrate, they paid attention to the work and accepted it well, because I thought it would be a bit difficult to accept it, 
[...] they were very receptive". Inquiring whether this material could be used in art classes, she replied that she could use it, not only for the arts but also for other disciplines, because she considered it possible through this game to work with different contents. She found the material easy to work with and said that the students were able to situate themselves inside the city, locating and identifying works that they had already seen, but whose history and authors did not know. Analyzing the results of the learning tests, it was possible to observe that the larger number of information brought by the students referred to the works they already knew before the experiment, which shows that this connection of the universal knowledge of art with the history of the city and the knowledge that the students already brought from their experiences was important in the learning process.

The teacher at school B also made a good evaluation of the game. After completing the study presented here, she received three complete kits with the game developed to continue using it in his school. The teacher said she intends to give training to other teachers in her school so that they also use the material. During the interview, the teacher stated that she had never worked with games, but that she had really enjoyed the experience. According to her, the students "loved" the game, they were immersed in it, being able to establish relations with the spaces they already knew in the city. In an informal conversation with this same teacher a few months after the study, she reported that the students identified the works of art in the places they passed in the city, which reveals that the game was able to bring to the students reality the universal knowledge of Art History, an important aspect of the learning process.

\section{CONCLUSIONS}

This paper presented a study about the development and use of a board game to support teaching and learning of arts. In the research conducted, the performance of the students of a control group who worked with a traditional approach based on oral lessons and atelier practices was compared to the performance of the students of an experimental group, considering the information that the students remembered about art works in the city. The results of the study showed that the experimental group and the control group had a statistically equivalent performance.

Earlier studies with similar experimental design also compared so-called "traditional" approaches and game-based learning. In a study about learning of fire-fighting with 3rd graders, Chuang and Chen (2009) observed superior performance of students who used the game-based approach when compared to students who followed a more traditional approach to teaching and learning. In the area of medicine, Rondon, Sassi and Andrade (2013) found that students who worked with traditional teaching and learning methods obtained better results in anatomy and physiology tests when compared to students who used a gaming approach. Such disparities occur because there are a number of other aspects related to to the teaching and learning approach used in the classroom, which may influence student performance such as social context, intervention time, area of knowledge, type of game used, among others. What is clear, in this sense, is the need for new studies that allow better delimiting benefits and limitations of game-based learning considering these different aspects. However, it should also be noted that, possibly, the most relevant discussion is not related to the ability of games to produce better or worse results than traditional teaching.

Good teachers may teach great lessons and this may not, in fact, be replaced by a game. The way educational games are brought to the classroom may be an important aspect to be debated. Games are often made without the participation of students or even teachers, being brought to the classroom as ready-made solutions. In the research presented here, the game involved students in its design and validation, until reaching its final format used in the study presented here. The dynamics for its use was also discussed with teachers, but it may certainly undergo improvements. Even so, several teachers from other disciplines who followed the development of the project in the two schools requested that adapted versions be made for other contents. The idea of this research was, precisely, to develop a game model that could be customized by teachers and students. Actions such as this involving students and teachers have the potential to broaden educational processes and may produce important results that go beyond the simple use of a game in the classroom. It was also possible to observe, in the study presented here, that the intervention with the board game to support art learning brought a satisfactory level of motivation to the students. Although complementary studies are needed 
to assess to what extent these results may be perpetuated in the long run, it was reported by one of the teachers who participated in the experiment that the students went on to identify the works present in the game in their city tours, often seeking their location and establishing a relation with the information present in the game.

Using the methodology of iterative design (SALEN; ZIMMERMAN, 2012), it was possible to build a game with mechanics that proved adequate to work with art contents. Another contribution of this research has been the very development of the game that focuses on specific contents about art in the city of Porto Alegre, Brazil. The works cataloged and used in the game represent an initial collection that may be expanded in future versions of the game. In order to allow the customization of the game by the teachers, the tabs of the board, with information about the works and where the players mark their moves, became detachable and easily replaceable, allowing new works of art to be inserted to work others contents.

As a proposal for future work, a new project phase is being set up in which the students themselves will go to a FabLab to construct the models of the works of art to be used in the board game that they themselves must construct and use.

\section{REFERENCES}

ACASO, Maria. Esto no son las Torres Gemelas: Como aprender a leer la televisión y otras imágenes. Madrid: Catarata, 2006.

BARBOSA, Ana Mae. As mutações do conceito e da prática. In: BARBOSA, Ana Mae (Ed.), Inquietações e mudanças no ensino da arte. São Paulo: Cortez, 2012, p. 13-27.

CSIKSZENTMIHALYI, Mihaly; NAKAMURA, Jeanne. The dynamics of intrinsic motivation: a study of adolescents. In CSIKSZENTMIHALYI, Mihaly (Ed.), Flow and the Foundations of Positive Psychology: The Collected Works of Mihaly Csikszentmihalyi. Dordrecht: Springer, 2014, p. 175-195.

CHUANG, Tsung-Yen; CHEN, Wei-Fan. Effect of Computer-Based Video Games on Children: An Experimental Study. Educational Technology \& Society, Denton (TX), v.12, n.2, p.1-10, 2009.

BROUGÈRE, Gilles. Jogo e educação. Tradução: Patrícia Chittoni Ramos. Porto Alegre : Artmed, 1998.

BROUGÈRE, Gilles. Repenser le jeu au regard de sa place au sein des industries culturelles. Paris: Nouveau Monde, 2015.

CALLOIS, Roger. Les jeux et les hommes: le masque et le vertige. Paris: Gallimard, 1991.

COSTA, Leandro Demenciano. O que os jogos de entretenimento têm que os educativos não têm: 7 princípios para projetar jogos educativos eficientes. Rio de Janeiro: Novas Ideias, 2010.

FRANGE, Lucimar Bello Pereira. Arte e seu ensino, uma questão ou várias questões? In: BARBOSA, Ana Mae (Ed.). Inquietações e mudanças no ensino da arte. São Paulo: Cortez, 2012, p. 37-51.

GALISI, Delmar. Videogames: ensino superior de jogos no Brasil. In: Santella, Lúcia (Ed.), Mapa do Jogo. São Paulo: Cengage Learning, 2009, p. 223-238.

KELLER, John. M. Development and use of the ARCS model of motivational design. Journal of instructional development, [s.1.], v. 10, n. 3, p. 2-10, 1987.

INEP Instituto Nacional de Estudos e Pesquisas Educacionais Anísio Teixeira. Censo Escolar 2017: Notas Estatísticas. Brasília: INEP, Janeiro, 2018. Disponível em: 
http://download.inep.gov.br/educacao_basica/censo_escolar/notas_estatisticas/2018/notas_estatistic as_Censo_Escolar_2017.pdf. Acesso em: 10 mar. 2019.

LINDEROTH, Jonas. Why gamers don't learn more: an ecological approach to games as learning environments. Journal of Gaming \& Virtual Worlds, v. 4, n. 1, p. 45-62, 2012.

LOPONTE, Luciana Gruppelli. Ensino de Artes Visuais: entre pesquisas e práticas. Revista Educação e Cultura Contemporânea, Rio de Janeiro, v. 11, n. 23, p. 166-167, 2014.

MACEDO, Lino de. Quatro cores, senha e dominó: oficinas de jogos em uma perspectiva construtivista e psicopedagógica. São Paulo: Casa do Psicólogo, 1997.

MANDRYK, Regan L.; MARANAN, Diego S.; INKPEN, Kori M. False Prophets: Exploring Hybrid Board/Video Games. In: CONFERENCE ON HUMAN FACTORS IN COMPUTING SYSTEMS CHI, Abril 20-25, 2002, Minneapolis, Minnesota, USA. Anais... New York, NY:ACM, 2002, p. 640641.

MARTINS, Miriam Celeste. Aquecendo uma tranforma-ação: atitudes e valores no ensino de artes. In: BARBOSA, Ana Mae (Ed.). Inquietações e mudanças no ensino da arte. São Paulo: Cortez, 2012, p. 52-65.

MATTAR, João. Games em educação: como os nativos digitais aprendem. São Paulo: Pearson Prentice Hall, 2010.

PAULA, Bruno Henrique de; VALENTE, José Armando. Jogos digitais e educação: uma possibilidade de mudança da abordagem pedagógica no ensino formal. Revista Ibero-americana de Educación, Madrid, v. 70, n. 1, p. 9-28, 2016.

PIAGET, Jean. La psychologie de L'intelligence. Paris: Collection Armand Colin, 1966.

PIAGET, Jean. O juízo moral na criança. Tradução Elzon Lenardon. São Paulo: Summus, 1994.

PRENSKY, Marc. Digital Natives, Digital Immigrants Part 1. On the Horizon, Bingley, Reino Unido, v. 9, n. 5, p. 1-6, 2001.

PRENSKY, Marc. Aprendizagem baseada em jogos digitais. Tradução Eric Ymagute. São Paulo: Senac, 2012.

RIZZI, Maria Cristina de Souza. Caminhos metodológicos. In: BARBOSA, Ana Mae (Ed.). Inquietações e mudanças no ensino da arte. São Paulo: Cortez, 2012, p. 69-77.

RONDON, Silmara; SASSI, Fernanda Chiarion; ANDRADE, Claudia Regina Furquim de. Computer game-based and traditional learning method: a comparison regarding students' knowledge retention. BMC Medical Education, Londres, Reino Unido, v. 13, n. 30, p. 1-8, 2013.

RYAN, Richard M.; DECI, Edward. L. Self-determination theory and the facilitation of intrinsic motivation, social development, and well being. American Psychologist, Washington (Estados Unidos), v. 55, n. 1, pp. 68-78, 2000.

SALEN, Katie; ZIMMERMAN, Eric. Regras do jogo: fundamentos do design de jogos: principais conceitos. Tradução Edson Furmankiewicz. São Paulo: Blucher, 2012.

SANTOS, Santa Marli Pires. Educação, arte e jogo. Petrópolis, RJ: Vozes, 2008. 
SAVI, Rafael. Avaliação de jogos voltados para a disseminação do conhecimento. 2011. Tese (Doutorado em Engenharia e Gestão do Conhecimento) - Programa de Pós-Graduação em Engenharia e Gestão do Conhecimento, Universidade Federal de Santa Catarina, Florianópolis, Santa Catarina, 2011.

SAVI, Rafael; ULBRICHT, Vania Ribas. Jogos Digitais Educacionais: Benefícios e Desafios. Renote Novas Tecnologias na Educação, Porto Alegre, v. 6, n. 2, p. 1-10, 2008.

SILVA, Maria do Carmo Potsch de Carvalho e; MOREIRA, Laélia Portela. O ensino da arte no Colégio Pedro II: resistência e mudança. Educação Por Escrito, Porto Alegre, v. 7, n. 1, p. 88-105, 2016.

TOHIDI, Hamid; JABBARI, Mohammad Mehdi. The effects of motivation in Education. Procedia Social and Behavioral Sciences, [s.1.], v. 31, n. 1, p. 820-824, 2012.

TOURINHO, Irene. Transformações no ensino da Arte: algumas questões para uma reflexão conjunta. In: BARBOSA, Ana Mae (Ed.). Inquietações e mudanças no ensino da arte. São Paulo: Cortez, 2012, p. 27-34.

VANDERCRUYSSE, Sylke; VANDERWAETERE, Mieke; CLAREBOUT, Geraldine. Game based learning: A review on the effectiveness of educational games. In: CRUZ-CUNHA, Maria Manuela (Ed.), Handbook of Research on Serious Games as Educational, Business, and Research Tools. Hershey, PA: IGI Global, 2012, p. 628-647.

Submission: 01/24/2019

Approval: 05/19/2019 